\title{
Research Paper: Organophosphorus Insecticide Poisoning Related Mortality and Neurotoxicity in Sabzevar
}

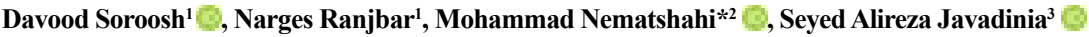 \\ 1. Department of Internal Medicine, School of Medicine, Sabzevar University of Medical Science, Sabzevar, Iran \\ 2. Department of Anesthesiology, School of Medicine, Sabzevar University of Medical Science, Sabzevar, Iran. \\ 3. Cellular and Molecular Research Center, Sabzevar University of Medical Sciences, Sabzevar, Iran.
}

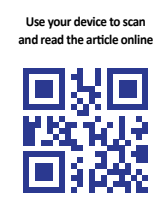

Citation: Soroosh D, Ranjbar N, Nematshahi M, Javadinia SA. Organophosphorus Insecticide Poisoning Related Mortality and Neurotoxicity in Sabzevar. International Journal of Medical Toxicology and Forensic Medicine. 2020; 10(2):27706. https:// doi.org/10.32598/ijmtfm.v10i2.27706

https://doi.org/10.32598/ijmtfm.v10i2.27706

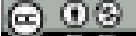

Article info:

Received: 03 Nov 2019

First Revision: 05 Nov 2019

Accepted: 11 Nov 2019

Published: 20 Jun 2020

\section{Keywords:}

Organophosphorus poisons, Mortality, Neurotoxicity

\section{ABSTRACT}

Background: This study aimed to assess mortality and neurotoxicity caused by the pesticide organophosphate and its correlation with the type of poison and treatment in patients admitted to Vasei Hospital of Sabzevar City, Iran, in 2018.

Methods: Out of 122 cases, 52 patients (43.3\%) were male, and 70 patients $(56.9 \%)$ were female. The Mean $\pm \mathrm{SD}$ age of the men was $32.65 \pm 29.15$, and women was $30 \pm 15.30$ years.

Results: Mortality in women and men was $10 \%$ and $17.3 \%$, respectively. Among treated people, diazinon had the highest frequency of $76.4 \%$, and among dead people from diazinon and malathion had the highest rates of $56.3 \%$ and $43.8 \%$, respectively.

Conclusion: The prevalence of mortality in patients was $7.3 \%(n=9)$. As most people with organophosphorus poisoning have been exposed to diazinon toxins; therefore, strategies to prevent and reduce exposure to this toxin are essential.

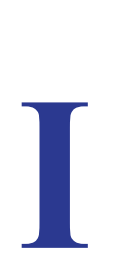

\section{Introduction}

$\mathrm{n}$ recent years, the prevalence of poisoning has increased dramatically due to the growth and development of societies and the ease of access to drugs and toxins [1]. Toxins are one of the most important causes of hospitalization today. In the United States, millions of people come to hospitals every year because of poisoning, and poisoning is high in Iran, too. Poisonings are the most crucial cause of specific diseases in many developed countries [2-4]. In general, the incidence of poisoning varies widely depending on the geographical region in every country [5].

Many of the poisonings are of the pharmacological type, and the rest of us are non-pharmacological poisonings, of which the common causes are drugs, hydrocarbons, organophosphorus toxins, natural or chemical anticholinergic compounds, dead rats, drugs, carbon monoxide, alcohol, fungi are bites of insects and animals and are acidic or playful (less abundant) $[5,6]$. In some areas, pesticides are used in particular to combat pests, especially organophosphate, and because of their ease of access,

* Corresponding Author:

Mohammad Nematshahi, PhD.

Address: Department of Anesthesiology, School of Medicine, Sabzevar University of Medical Science, Sabzevar, Iran.

Tel: +98 (51) 44014091

E-mail:nematshahim@medsab.ac.ir 
they are more common than other types of poisoning, so poisoning is more common. With organophosphorus compounds, one of the major clinical problems in the world, especially the third world countries, is associated with a high mortality rate $[5,7]$.

Following organophosphorus poisoning, there are four clinical stages, three acute and one chronic: acute cholinergic crisis, interstitial syndrome, organophosphorusinduced delayed neuropathy, chronic organophosphateinduced neuropsychiatric disorder. This study aimed to determine the rate of mortality and neurotoxicity due to organophosphorus toxins and its relationship with the type of poison and treatment performed in patients.

\section{Materials and Methods}

This cross sectional study was performed at the Vasei Hospital in 2018. The inclusion criteria were a definitive diagnosis of organophosphorus poisoning based on clinical and patient evidence and completeness of information needed in patient records. The diagnosis of organophosphorus poisoning in this study was based on patient history and patient companionship as well as a measurement of serum butyrylcholinesterase.

Given the prevalence of organophosphorus pesticides at the community level, 95\% confidence level, and $0.2 \%$ accuracy, the sample size was estimated to be approximately 120 . The study data were collected using a researcher-made checklist, including information about the patient's gender and age, the name of the toxin used, referral to another facility, initial treatment, type of medication taken at the facility, symptoms of the patient on admission, and condition at discharge were collected.

Neuropsychiatric symptoms were assessed at the first visit and three weeks later. The indices of Mean \pm SD were used to describe the quantitative variables and frequency and percentage for qualitative variables. The $t$ test was used to compare the mean quantitative outcomes between the two groups. The Chi-square test or Fisher exact test was used to compare the qualitative variables between the groups.

\section{Results}

In this study, a total of 122 subjects met the inclusion criteria. Of these patients, 52 patients $(43.3 \%)$ were male, and $70(56.9 \%)$ were female. The mean age in male patients was 32.651515 .29 years with the youngest and highest age being 3 and 81 years, and the mean age in females was 30.001515 .39 years ranged 4-91 years.
The mortality rate was $10 \%(\mathrm{n}=7)$ in women and $17.3 \%$ $(n=9)$ in men. The Fisher exact test results showed no significant difference between men and women in mortality rate due to organophosphorus poisoning $(\mathrm{P}=0.28)$ (Table 1).

Table 2 presents the frequency distribution of the type of treatment and its association with morbidity and mortality in patients exposed to organophosphorus. The treatments include using atropine, gastric washing, sorbitol, charcoal, pralidoxime, pantoprazole, and ranitidine:

Treatment 1, atropine; treatment 2, gastric washing; treatment 3, sorbitol; treatment 4, atropine, gastric washing, sorbitol, charcoal, pralidoxime, pantoprazole, and ranitidine; treatment 5 , ranitidine; treatment 6 , atropine and ranitidine; treatment 7 , atropine, gastric washing, sorbitol, charcoal, pralidoxime, pantoprazole, ranitidine intubation; and treatment 8, atropine, gastric washing, sorbitol, and charcoal.

\section{Discussion}

In the present study, $56.9 \%$ of the patients with organophosphorus intoxication were female, and $43.3 \%$ were male. This indicates a higher rate of poisoning in women than in men. The mean age for men was 32.65 years, and for women 30.00 years. Razwiedan conducted a study in South Africa between 2012 and 2014 on 207 patients who were $58 \%$ male and $42 \%$ female. Women under 30 were mostly affected by organophosphorus poisoning.

The age range of people affected by organophosphorus poisoning was between 10 months and 59 years. Poisoning was deliberate in $51.7 \%$, accidental in $21.7 \%$, and without any known cause in 26.6\% [8]. In Ghaffar Ali Mahmoodi et al. study on 153 patients with organophosphorus poisoning, the highest rate of organophosphorus poisoning was found in the age ranged $17-21$ years, with $57.6 \%$ of female poisoning and $42.4 \%$ of male poisoning [9].

In Gannur et al. study, the highest incidence of intoxication was observed in young people (16-30 years) [10] Yazdani Nejad et al. conducted a study between 2012 and 2013 at Loghman Hakim Hospital on 201 patients. About $47 \%$ of patients were female, and $52 \%$ were male. Their mean age was 33 years ranged 2-89 years. Of 201 patients, 18 died, and 183 survived. Diazinon was the most abundant toxin with $15 \%$, followed by malathion, chlorpyrifos, and cyhalothrin with $7 \%, 6 \%$, and $0.5 \%$, respectively. 
Table 1. Frequency distribution of mortality and toxicity complications by the type of toxin in people exposed to organophosphorus

\begin{tabular}{|c|c|c|c|c|c|c|}
\hline \multirow{2}{*}{ Variables } & \multicolumn{4}{|c|}{ No. (\%) } & \multirow{2}{*}{ Total } & \multirow{2}{*}{$\mathbf{P}$} \\
\hline & Malathion & Parathion & Diazinon & Demeton & & \\
\hline Mortality & $7(43.8)$ & $0(0)$ & $9(56.3)$ & $0(0)$ & 16 & 0.111 \\
\hline Delayed neuropathy & $1(25)$ & $1(25)$ & $2(50)$ & $0(0)$ & 4 & 0.118 \\
\hline Intermediate syndrome & $4(23.5)$ & $2(11.8)$ & $11(64.7)$ & $0(0)$ & 17 & 0.353 \\
\hline Seizure & $1(10)$ & $0(0)$ & $8(80)$ & $1(10)$ & 10 & 0.006 \\
\hline Headache & $2(28.6)$ & $0(0)$ & $5(71.4)$ & $0(0)$ & 7 & 0.907 \\
\hline Dizziness & $0(0)$ & $0(0)$ & $1(100)$ & $0(0)$ & 1 & 0.949 \\
\hline
\end{tabular}

Table 2. Frequency distribution of the type of treatment and its relation to morbidity and mortality

\begin{tabular}{|c|c|c|c|c|c|c|c|c|c|c|}
\hline \multirow[b]{2}{*}{ Variables } & \multicolumn{8}{|c|}{ No. (\%) } & \multirow[b]{2}{*}{ Total } & \multirow[b]{2}{*}{$\mathbf{P}$} \\
\hline & $\begin{array}{l}\text { Treat- } \\
\text { ment } 1\end{array}$ & $\begin{array}{c}\text { Treat- } \\
\text { ment } 2\end{array}$ & $\begin{array}{c}\text { Treat- } \\
\text { ment } 3\end{array}$ & $\begin{array}{c}\text { Treat- } \\
\text { ment } 4\end{array}$ & $\begin{array}{c}\text { Treat- } \\
\text { ment } 5\end{array}$ & $\begin{array}{c}\text { Treat- } \\
\text { ment } 6\end{array}$ & $\begin{array}{c}\text { Treat- } \\
\text { ment } 7\end{array}$ & $\begin{array}{c}\text { Treat- } \\
\text { ment } 8\end{array}$ & & \\
\hline Mortality & 0 & 0 & 0 & $1(6.25)$ & 0 & 0 & $\begin{array}{c}15 \\
(93.75)\end{array}$ & 0 & 16 & 0.111 \\
\hline $\begin{array}{l}\text { Delayed } \\
\text { neuropathy }\end{array}$ & 0 & 0 & 0 & $4(100)$ & 0 & 0 & 0 & 0 & 4 & 0.118 \\
\hline $\begin{array}{l}\text { Intermediate } \\
\text { syndrome }\end{array}$ & $1(1)$ & 0 & 1 (5) & $7(41)$ & 0 & $2(11)$ & 0 & 0 & 17 & 0.353 \\
\hline Seizure & 0 & 0 & 0 & $8(80)$ & 0 & 0 & $1(10)$ & $1(10)$ & 10 & 0.006 \\
\hline Headache & 0 & 0 & 0 & $4(57)$ & 0 & $2(28)$ & $1(14)$ & 0 & 7 & 0.907 \\
\hline Dizziness & 0 & 0 & 0 & $4(57)$ & 0 & $2(28)$ & $1(14)$ & 0 & 1 & 0.949 \\
\hline
\end{tabular}

In $93 \%$ of them, poisoning was by mouth and in $7 \%$ by other methods like inhalation, injections, and so on. In $85 \%$ of cases, the use of organophosphorus pesticides was deliberate, and in 14\%, it was accidental [11]. Umakanth et al. investigated the prevalence of organophosphorus poisoning in Sri Lanka. They studied 121 patients, 98\% of whom had deliberate intoxication, and only $1.65 \%$ had accidental poisoning. All patients had oral toxicity. Of 121 patients, $68 \%$ were female, and $38 \%$ male, most of them were in the age group of 12-29 years [12].

Banday et al. investigated the mortality rate of organophosphorus pesticides among 133 patients during 2015. About $76 \%$ of them were male, and $24 \%$ were female, and most of them were under 40 years old. Of the 133 poisoned patients, $98 \%$ had oral poisoning, and $36 \%$ of these patients recovered after gastric lavage and were discharged after three days. The mortality rate was 33\% in these patients [13].
Yurumez et al. investigated the acute toxicity of organophosphorus from 1995-2004 in 220 patients (59\% female and $41 \%$ male). The age group of 14-24 was also more prevalent than the other age groups. The oral method was the most common method of intoxication and suicide poisoning (75\%). The most common types of organophosphate poisoning were dichlorvos, diazinon, and parathion-methyl. The mortality rate was $9 \%$ in patients exposed to organophosphorus [14].

Kang et al. investigated 68 patients to evaluate survival factors in organophosphate poisoning. Their mean age was 54 years, and 56\% were male, and the rest were female. The most common organophosphorus toxins are dichlorvos, O-ethyl-O-(4-nitrophenyl) phenylphosphonothioate, phosphamidon, phenthoate, and malathion with $30 \%, 17 \%, 11 \%, 4 \%$, and $3 \%$, respectively. The mortality rate was $19 \%$ in these patients [15]. 
Diazinon was the most prevalent poison among live patients, Although, among dead patients, Diazinon and Malathion had the highest frequency (56.3 and 43.8\%, respectively).

\section{Conclusion}

According to the results of this study, the prevalence of organophosphorus poisoning was higher in females, but there was no significant difference in the mortality rate due to organophosphorus poisoning between men and women. The mean age of men and women exposed to organophosphorus poisoning was 30 and 32.65 years, respectively. The organophosphate poisoning was caused by Diazinon mostly.

\section{Ethical Considerations}

\section{Compliance with ethical guidelines}

The Ethics Committee of Sabzevar University of Medical Sciences approved this study (Code: IR.MEDSAB. REC.1396.49). Written informed consent form has been obtained from patients or their legal guarantees.

\section{Funding}

This article was supported by Sabzevar University of Medical Science (Grant Number: 96030).

\section{Author's contributions}

All authors contributed in preparing this article.

\section{Conflict of interest}

The authors declared no conflict of interest.

\section{Reference}

[1] Moghaddamnia AA. [Suruey of acute suicidal poisoning in the west of Mazandaran province during the years 1373 76 (Persian)]. J Mazandaran Univ Med Sci. 1999; 9(22):18-25. http://jmums.mazums.ac.ir/article-1-919-en.html

[2] Moghadamnia A, Hallagisani S. [Study of acute poisoning in Ramsar (Persian)]. J Qazvin Uni Med Sci. 1999; 3(2):43-9. http:/ / journal.qums.ac.ir/browse.php?a_id=538\&sid=1\&slc_lang=en

[3] Marx J, Walls R, Hockberger R. Rosen's emergency medicine-concepts and clinical practice e-book: Elsevier Health Sciences; 2013. https://www.elsevier.com/books/rosensemergency-medicine-concepts-and-clinical-practice-2-volume-set/marx/978-1-4557-0605-1
[4] Paudyal BP. Poisoning: Pattern and profile of admitted cases in a hospital in central Nepal. JNMA J Nepal Med Assoc. 2005; 44(159):92-6. https:/ / www.ncbi.nlm.nih.gov/pubmed/16554862

[5] Moghadamnia AA, Abdollahi M. An epidemiological study of poisoning in northern Islamic Republic of Iran. East Mediterr Health J. 2002; 8(1):88-94. https://www.ncbi.nlm.nih. gov/pubmed/15330564

[6] Ghorashi Z, Sultani Ahari H. [A study of the acute poisoning in patients admitted to Tabriz pediatrics medical center (Persian)]. J Ardabil Uni Med Sci. 2003; 3(9):59-64. https:/ / www. sid.ir/en/journal/ViewPaper.aspx?id=28954

[7] Kanchan T, Menezes RG. Suicidal poisoning in Southern India: Gender differences. J Forensic Leg Med. 2008; 15(1):7-14 [DOI:10.1016/j.jflm.2007.05.006] [PMID]

[8] Razwiedani LL, Rautenbach P. Epidemiology of organophosphate poisoning in the tshwane district of south Africa. Environmental health insights. 2017; 11:1178630217694149. https://www.ncbi.nlm.nih.gov/pubmed/28469445

[9] Mahmoudi GH, Asaee R. [Epidemiologic study of Organophosphate and Organochlorate pesticides poisoning in hospitalized patients in Khorramabad Shohada Ashayer hospital from Mars to August 2006 (Persian)]. Yafteh. 2008; 10(1):310. http://yafte.lums.ac.ir/browse.php?a_code=A-10-1 150\&slc_lang $=$ en\&sid $=1$

[10] Gannur DG, Maka P, Nararyan Reddy KS. Organophosphorus compound poisoning in Gulbarga region - A five year study. Indian J Forensic Med Toxicol. 2008; 2(1):3-11. http:// www.i-scholar.in/index.php/ijfmt/article/view/45739

[11] Raouf Yazdinejad S, Emamhadi M, Okazi MA, Memarian A. Risk factors for mortality in organophosphate poisoned patients. Int J Med Toxicol and Forensic Med. 2014 5(2):73-7. http://journals.sbmu.ac.ir/ijmtfm/article/view/ IJMTFM-6980

[12] Umakanth M. Prevalence of organophosphate poisoning in Batticaloa, Sri Lanka. Asia Pac J Med Toxicol. 2017; 6(4):1157. http://apjmt.mums.ac.ir/article_10599.html

[13] Banday TH, Tathineni B, Desai MS, Naik V. Predictors of morbidity and mortality in organophosphorus poisoning: A case study in rural hospital in Karnataka, India. N Am J Med Sci. 2015; 7(6):259-65. [DOI:10.4103/1947-2714.159331] [PMID] [PMCID]

[14] Yurumez Y, Durukan P, Yavuz Y, Ikizceli I, Avsarogullari L, Ozkan S, et al. Acute organophosphate poisoning in university hospital emergency room patients. Intern Med. 2007; 46(13):965-9. [DOI:10.2169/internalmedicine.46.6304] [PMID]

[15] Kang EJ, Seok SJ, Lee KH, Gil HW, Yang JO, Lee EY, et al. Factors for determining survival in acute organophosphate poisoning. Korean J Intern Med. 2009; 24(4):362-7. [DOI:10.3904/kjim.2009.24.4.362] [PMID] [PMCID] 